\title{
Pengolahan Bioarang sebagai Pengganti Biogas untuk Mendukung Proses Roasting Pengolahan Kopi Arabica dan Ketahanan Energi
}

\author{
Benedictus Mardwianta ${ }^{1}$, Abdul Haris Subarjo ${ }^{2 *}$, Dedet Hermawan S. ${ }^{3}$, Munawar Husaini ${ }^{4}$ \\ 1,2,3,4Jurusan Teknik Mesin, Institut Teknologi Dirgantara Adisutjipto, Indonesia \\ Email: ab.haris.79@mail.com*
}

Received: October 18, 2021; Accepted : November 2, 2021; Published : November 2, 2021

\begin{abstract}
Processing of waste biochar into briquettes as a substitute for biogas to support the roasting process of Arabica coffee processing is an alternative energy innovation as a substitute for conventional charcoal derived from wood and biogas from LPG as well as to support energy security. Briquette is a material that is strongly influenced by the nature and type of the materials that make it up. This study aims to determine the effect of the composition of briquettes with a mixture of coffee husk waste and sawdust on the calorific value, moisture content, ash content, and density test. The method used is experimental. In composition III the density value is the highest because the amount of sawdust is the most. because with the treatment of the compressive force manually, the charcoal particles will experience compression in accordance with the given compressive force. The results of the research on composition I yielded a calorific value of $6052 \mathrm{cal} / \mathrm{gr}$, composition II yielded a calorific value of $6122 \mathrm{cal} / \mathrm{gr}$ and composition III yielded a calorific value of 6333 cal/gr. The results of the ash content test of SNI 01-6235-2000 regarding charcoal briquettes, the permissible ash content does not exceed the value of $8 \%$. The ash content produced in composition III is according to the specified standard.
\end{abstract}

Keywords: Biochar briquettes, Coffee husk, Wood powder, Calorific value

ABSTRAK
Pengolahan limbah bioarang menjadi briket sebagai pengganti biogas untuk mendukung proses roasting pengolahan kopi arabica adalah inovasi energi alternatif sebagai pengganti arang konvensional yang berasal dari kayu dan biogas dari LPG serta untuk mendukung ketahanan energi. Briket merupakan material yang sangat dipengaruhi oleh sifat dan jenis dari bahan yang menjadi penyusun. Penelitian ini bertujuan untuk mengetahui pengaruh komposisi briket dengan campuran limbah kulit kopi dan serbuk kayu terhadap nilai kalor, kadar air, kadar abu, dan uji kerapatan. Metode yang digunakan adalah eksperimen. Pada komposisi III nilai kerapatan paling tinggi karena jumlah serbuk kayu paling banyak. karena dengan adanya perlakuan gaya tekan secara manual maka partikel arang akan mengalami pemampatan sesuai dengan gaya tekan yang diberikan. Hasil penelitian komposisi I menghasilkan nilai kalor $6052 \mathrm{kal} / \mathrm{gr}$, komposisi II menghasilkan nilai kalor $6122 \mathrm{kal} / \mathrm{gr}$ dan komposisi III menghasilkan nilai kalor $6333 \mathrm{kal} / \mathrm{gr}$. Hasil uji kadar abu SNI 01-62352000 tentang briket arang, kadar abu yang diperbolehkan tidak melebihi nilai 8\%. Kadar abu yang dihasilkan pada komposisi III sesuai standar yang ditentukan.

Kata Kunci : Briket bioarang, Kulit kopi, Serbuk kayu, Nilai kalor

\section{PENGANTAR}

Kebutuhan energi dunia semakin meningkat dari tahun ke tahun, seiring dengan pertambahan jumlah penduduk dunia. Aktivitas manusia yang memerlukan bahan bakar sebagai sumber energi turut berperan dalam mempercepat berkurangnya jumlah ketersediaan energi, hal ini ditambah dengan semakin menipisnya cadangan sumber energi yang tersedia [1]. Energi merupakan komponen utama dalam seluruh kegiatan makhluk hidup. Sumber energi yang utama bagi manusia adalah sumber daya alam yang berasal dari fosil karbon [2]. ketahanan energi sebagai salah satu prioritas pembangunan nasional yang telah ditetapkan oleh pemerintah [3]. Ketahanan energi merupakan kondisi terjaminnya ketersediaan energi, masyarakat dapat menjangkau energi dengan harga yang terjangkau dalam waktu jangka panjang dan tidak terpengaruh gejolak regional maupun internasional [4]. Ketahanan energi nasional memiliki ciri: 1) terjaminnya ketersediaan energi (availability), 2) akses masyarakat terhadap energi dengan harga terjangkau (accessibility 
and affordability), 3) memiliki pasokan jangka panjang (sustainability), 4) terdapat program perlindungan lingkungan hidup [5]. Kebutuhan kompor untuk memasak tidak terlepas dari penggunaan energi. Besarnya biaya pembelian listrik dan harga gas semakin naik dan akan dapat membebani masyarakat Indonesia [6]. Dari sini muncul ide untuk menciptakan sumber energi alternatif briket bioarang dari bahan baku terbarukan

Penelitian karakterisasi briket bioarang dengan variasi komposisi kulit kopi menggunakan perbedaan komposisi kulit kopi dengan 3 level (30\%, 50\% dan 70\%) dan dengan komposisi perekat sama pada setiap perlakuannya yakni $20 \%$ dan dilakukan pengulangan 3 kali setiap komposisi kulit kopi sehingga diperoleh 9 satuan percobaan. Data yang diperoleh yaitu nilai Kalor, kadar air, kadar abu, volatile mass, karbon terikat, dan kuat tekan aksial selanjutnya dilakukan analisa deskriptif pada presentase gafik hasil pengujian pada setiap perlakuan penelitian dengan hasil nilai kalor optimal 4923,9 Kal/g pada presentase kulit kopi 30\%, hal ini masih kurang dari standar briket batu bara rumah tangga yang memiliki standar minimal 5000 - $6300 \mathrm{Kal} / \mathrm{g}$. Kadar air yang paling kecil pada persentase kulit kopi 30\% yakni 6,275\% hal ini memenuhi standar Dirjen Pertambangan $<7,5 \%$. Sedangkan pada volatile mass yang paling kecil sebesar 9,862\% pada persentase $70 \%$ kulit kopi, masih kurang dari standar minimal sebesar $12 \%$ - 15\%. Nilai kadar abu paling rendah sebesar 19,304 \% pada $70 \%$ kulit kopi dan yang tertinggi pada persentase $30 \%$ yakni $32,82 \%$ masih kurang dari standar minimal $<8 \%$. pada nilai karbon terikat yang terendah $49,46 \%$ pada persentase kulit kopi $30 \%$ dan paling tinggi pada persentase $70 \%$ kulit kopi yakni $62,751 \%$. Kuat tekan yang paling tinggi $0,198 \mathrm{~kg} / \mathrm{cm}^{2}$ pada persentase kulit kopi $30 \%$, tetapi hal ini masih kurang dari standar minimal 3 $\mathrm{kg} / \mathrm{cm}^{2}[7]$.

Penelitian tentang biomassa cangkang kopi, dengan pengujian kadar karbon, kandungan sulfur oksida, kadar abu dan airnya, dengan mencampur bottom ash dengan biomassa cangkang kopi menggunakan pengikat tetes tebu. Variasi perbandingan antara bottom ash dan biomassa adalah; 50:50, 60:40 dan 70:30. Pengujian kadar karbon dan kandungan sulfur oksida menggunakan SEM (Scanning Electron Microscope), menunjukkan pada komposisi bottom ash yang sedikit bisa menaikkan kadar karbon dan menurunkan kandungan sulfur oksida. Kadar karbon naik 7,25\%. Pada pengujian kadar air 3,93\%. Sedangkan pengujian kadar abu menunjukkan kenaikan 11,09\% [8].

Penelitian pembuatan briket dari campuran kulit kopi (coffea arabica) dan serbuk kayu menggunakan getah pinus (Pinus merkusii) sebagai perekat, perbandingan antara serbuk kayu dan kulit kopi dengan perbandingan 90:10, 70:30. 50:50, 30:70, 10:90. Dilakukan pengujian uji kerapatan, kuat tekan, kadar air, kadar abu, volatile meter, karbon terikat dan nilai kalor. Hasil kerapatan berkisar 0,56-0,72 g/ $/ \mathrm{cm}^{3}$, kuat tekan 1,66-5,36, $\mathrm{kg} / \mathrm{cm}^{2}$, kadar air berkisar $3594,20 \%$, kadar abu berkisar $0,12-0,28 \%$, volatile matter berkisar 89,8-91,7\%, karbon tetap berkisar 3,95-6,02 dan nilai kalor 5532,89-6124,06 Kal/g. Berdasarkan penelitian, komposisi briket berpengaruh terhadap nilai Kalor yang dihasilkan dari pencampuran serbuk kayu dan kulit kopi. Nilai kalor terbaik pada perbandingan serbuk kayu dan kulit kopi 70:30 dengan nilai 6124,0695 Kal/g sedangkan nilai kalor terendah pada perbandingan 10:90 yaitu 5532,8981 Kal/g [9].

Pemanfaatan limbah kulit kopi dan serbuik gergaji menjadi briket dapat sebagai sumber energi alternatif, dengan bahan baku kulit kopi dan serbuk kayu dengan bahan perekat tepung tapioka, pengujian yang dilakukan yaitu pengujian kadar air, kadar abu, zat terbang, karbon tertambat, dan nilai kalor. Hasil pengujian dengan variasi suhu karbonisasi yaitu $250^{\circ} \mathrm{C}, 300^{\circ} \mathrm{C}, 350^{\circ} \mathrm{C}, 400^{\circ} \mathrm{C}$, dan $450^{\circ} \mathrm{C}$ selama 2 jam. Kemudian variasi komposisi campuran limbah kulit kopi dan serbuk kayu dengan perbandingan, $75 \%$ kulit kopi, 25\% serbuk kayu (spesimen 1) dan 25\% kulit kopi, 75\% serbuk kayu (spesimen 2), serta bahan perekat tepung tapioka $8 \%$. pengaruh komposisi suhu pada pembuatan briket kulit kopi dan serbuk kayu yang optimum pada suhu $450^{\circ} \mathrm{C}[10]$.

Untuk merekatkan partikel zat dalam bahan baku pada proses pembuatan briket diperlukan zat perekat sehingga dihasilkan briket yang kompak [11]. Berdasarkan jenis bahan baku perekat sebagai pengikat untuk pembuatan briket, yaitu: Pengikat anorganik (Pengikat anorganik dapat menjaga ketahanan briket selama proses pembakaran sehingga dasar permeabilitas bahan bakar tidak terganggu. Pengikat organik (menghasilkan abu yang relatif sedikit setelah pembakaran briket dan umumnya merupakan bahan perekat yang efektif [12].

\section{METODE PENELITIAN}

Tahapan penelitian yang dilakukan dapat diketahui melalui gambar diagram alir yang disajikan pada Gambar 1. 


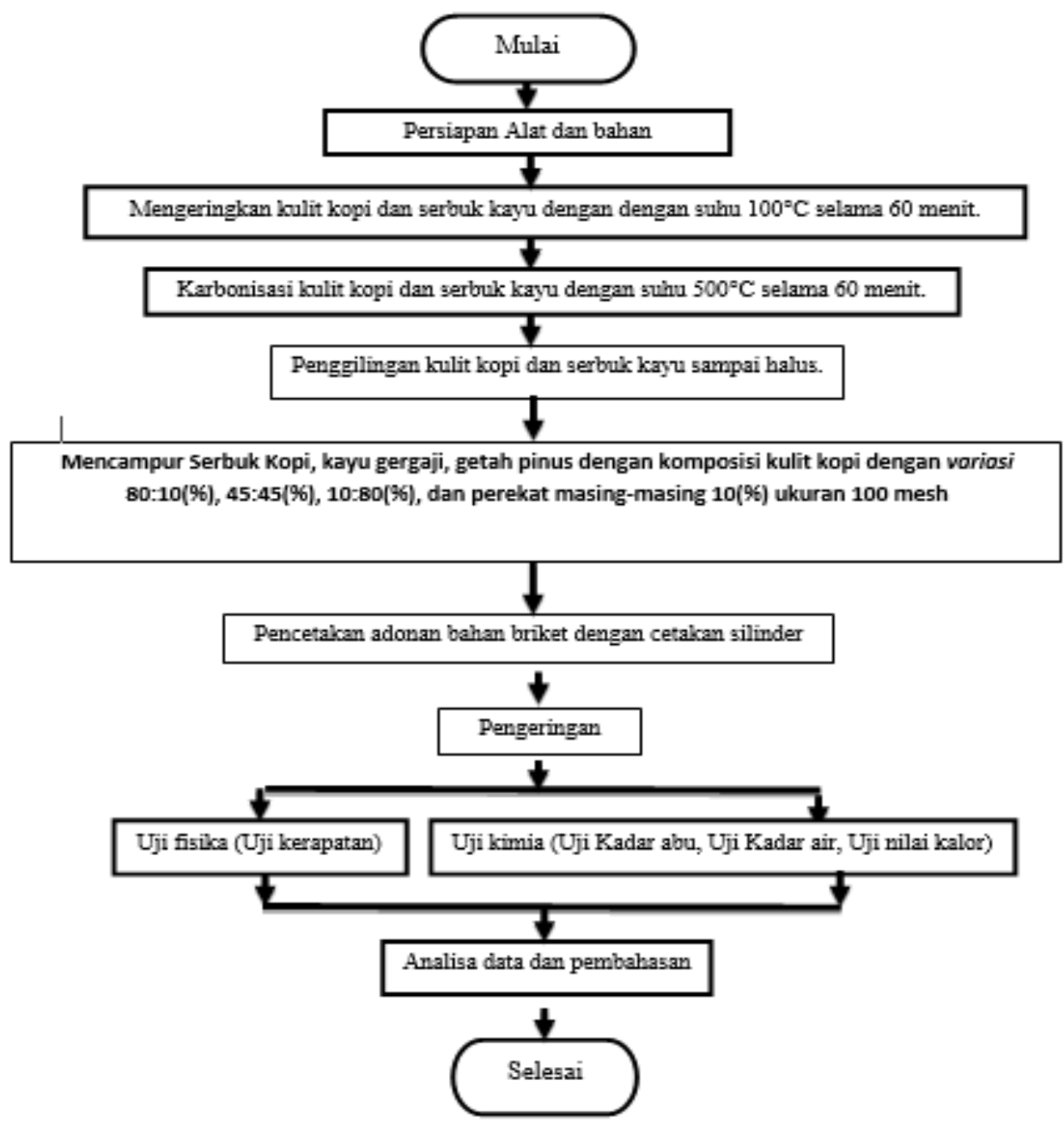

Gambar 1. Diagram alir Penelitian

Metode penelitian yang digunakan penelitian merupakan penelitian experimental deskriptif dengan menggunakan kombinasi komposisi kulit kopi dan serbuk kayu sebagai bahan baku briket bioarang yang dengan proses karbonisasi. Penelitian menggunakan perbedaan komposisi kulit kopi dengan variasi 80:10(\%), 45:45(\%), 10:80(\%), dan perekat masing-masing 10(\%), dilakukan pengulangan 2 Kali pada setiap komposisi kulit kopi sehingga diperoleh 6 percobaan. Data diperoleh dengan proses pengujian kerapatan, nilai kalor, kadar air, dan kadar abu. Kemudian dilakukan analisa pada presentase gafik hasil pengujian pada setiap penelitian.

Tahapan proses pembuatan briket bioarang yaitu mengeringkan kulit kopi dan serbuk kayu mengunakan oven pada suhu $100^{\circ} \mathrm{C}$ selama 1 jam, kemudian dilakukan proses karbonisasi kulit kopi dan serbuk kayu selama 1 jam dengan suhu $500^{\circ} \mathrm{C}$. Haluskan kulit kopi dan serbuk kayu yang sudah dikarbonisasi dengan mesin penghalus kemudian disaring dengan ayakan 100 mesh. Setelah proses penyaringan dilanjutkan pengadonan bahan baku sesuai perlakuan komposisi tiap variasi. Kemudian lakukan pencetakan briket bioarang dan ditekan dengan alat tekan. Setelah dicetak, bioarang dikeringkan dengan suhu ruangan selama 24 jam.

\section{Perhitungan pembuatan briket}

a. Menentukan Volume Cetakan (Vc)

$$
\begin{aligned}
\text { Vc } & =\text { Luas Alas } \times \text { Tinggi } \\
\text { Vc } & =\Pi . r 2 \times \mathrm{t} \\
& =3,14 \times 2^{2} \times 5 \mathrm{~cm}^{3} \\
& =62,8 \mathrm{~cm}^{3}
\end{aligned}
$$

b. Menentukan Volume Perekat (Vp) 
Volume fraksi perekat $10 \%$

$\mathrm{Vp}=\mathrm{Vf} \times \mathrm{Vc}$

$$
\begin{aligned}
& =\frac{10}{100} \times 62,8 \mathrm{~cm}^{3} \\
& =6,28 \mathrm{~cm}^{3}
\end{aligned}
$$

c. Menentukan volume serbuk kopi (Vk)

Volume fraksi serbuk kopi $80 \%$

$$
\begin{aligned}
\mathrm{Vk} & =\mathrm{Vf} \times \mathrm{Vc} \\
= & \underline{80} \times 62,8 \mathrm{~cm}^{3} \\
100 & =50,24 \mathrm{~cm}^{3}
\end{aligned}
$$

\section{Volume fraksi serbuk kopi $45 \%$}

$\mathrm{Vk}=\mathrm{Vf} \times \mathrm{Vc}$

$$
\begin{gathered}
=\frac{45}{100} \times 62,8 \mathrm{~cm}^{3} \\
=28,26 \mathrm{~cm}^{3}
\end{gathered}
$$

Volume fraksi serbuk kopi $10 \%$

$$
\begin{aligned}
\mathrm{Vk} & =\mathrm{Vf} \times \mathrm{Vc} \\
= & \underline{10} \times 62,8 \mathrm{~cm}^{3} \\
& =6,28 \mathrm{~cm}^{3}
\end{aligned}
$$

d. Menentukan volume serbuk gergaji (Vg)

Volume fraksi serbuk Gergaji $10 \%$

$\mathrm{Vg}=\mathrm{Vf} \times \mathrm{Vc}$

$$
\begin{aligned}
= & \frac{10}{100} \times 62,8 \mathrm{~cm}^{3} \\
= & 6,28 \mathrm{~cm}^{3}
\end{aligned}
$$

\section{Volume fraksi serbuk Gergaji $45 \%$}

$$
\begin{aligned}
\mathrm{Vg} & =\mathrm{Vf} \times \mathrm{Vc} \\
& =\frac{45}{100} \times 62,8 \mathrm{~cm}^{3} \\
& =28,26 \mathrm{~cm}^{3}
\end{aligned}
$$

\section{Volume fraksi serbuk Gergaji $80 \%$}

$$
\mathrm{Vg}=\mathrm{Vf} \times \mathrm{Vc}
$$

$$
\begin{aligned}
= & \frac{80}{100} \times 62,8 \mathrm{~cm}^{3} \\
= & 50,24 \mathrm{~cm}^{3}
\end{aligned}
$$

e. Menentukan Massa bahan briket

Massa Perekat (Mp)

Massa jenis getah pinus (perekat) $=1,089 \mathrm{gr} / \mathrm{cm}^{3}$

$$
\begin{aligned}
\mathrm{Mp} & =\mathrm{Vp} \times \mathrm{pf} \\
& =6,28 \mathrm{~cm} 3 \times 1,089 \mathrm{gr} / \mathrm{cm} 3 \\
& =6,83 \mathrm{gr}
\end{aligned}
$$

\section{Massa Serbuk Kulit Kopi (Mk)}

Massa jenis serbuk kulit kopi $=0,34 \mathrm{gr} / \mathrm{cm}^{3}$

$$
\begin{aligned}
& \operatorname{Mk}(80 \%)=\mathrm{Vk} \times \mathrm{pf} \\
& =50,24 \times 0,34 \mathrm{gr} / \mathrm{cm}^{3} \\
& =17,08 \mathrm{gr} \\
& \begin{aligned}
\mathrm{Mk}(45 \%)= & \mathrm{Vk} \times \mathrm{pf} \\
= & 28,26 \times 0,34 \mathrm{gr} / \mathrm{cm}^{3} \\
= & 9.60 \mathrm{gr}
\end{aligned}
\end{aligned}
$$




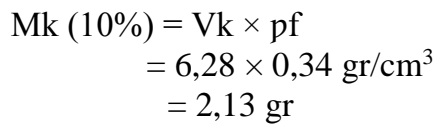

Massa Serbuk Gergaji (Mg)

Massa jenis serbuk gergaji $=0,21 \mathrm{gr} / \mathrm{cm}^{3}$

$\mathrm{Mg}(10 \%)=\mathrm{Vg} \times \mathrm{pf}$

$=6,28 \times 0,21 \mathrm{gr} / \mathrm{cm}^{3}$

$=1,31 \mathrm{gr}$

$\operatorname{Mg}(45 \%)=\mathrm{Vg} \times \mathrm{pf}$

$=28,26 \times 0,21 \mathrm{gr} / \mathrm{cm}^{3}$

$=5,93 \mathrm{gr}$

$\mathrm{Mk}(80 \%)=\mathrm{Vg} \times \mathrm{pf}$

$=50,24 \times 0,21 \mathrm{gr} / \mathrm{cm}^{3}$

$=10,55 \mathrm{gr}$

\section{Proses pembuatan briket}

a.. $\quad$ Menyiapkan alat dan bahan yang akan digunakan dalam proses pembuatan briket.

b. Melakukan pembakaran pada kulit kopi dan serbuk kayu supaya kadar air yang terkadung pada bahan tersebut berkurang.

c. Menyiapkan perekat briket yang akan digunakan, perekat yang terbuat dari getah pinus.

d. Melakukan penggilingan pada kulit kopi dan serbuk kayu yang telah dilakukan proses pembakaran

e. Melakukan pengayakan pada serbuk kulit kopi yang serbuk kayu dengan ukuran 100 mesh

f. Melakukan pengadonan serbuk kulit kopi dan serbuk kayu sesuai komposisi.

g. Melakukan pencetakan, kemudian masukkan ke oven hingga mengering.

h. Melakukan pengujian pada briket.

\section{Uji Kualitas Mutu Briket}

\section{Uji Fisika}

a. Kerapatan

Menimbang berat briket, mengukur volume briket dan menghitung densitas briket (volume silinder) dengan rumus:

$\rho=\mathrm{m} / \mathrm{y}$
Keterangan: $\quad \rho:$ Kerapatan $\left(\mathrm{kg} / \mathrm{cm}^{3}\right)$
$\mathrm{m}:$ massa $(\mathrm{kg})$
$\mathrm{v}:$ volume $\left(\mathrm{m}^{3}\right)$

\section{Uji kimia}

Memanaskan cawan porselin ke dalam oven pada suhu $105^{\circ} \mathrm{C}$ selama 30 menit, kemudian mendinginkan di dalam desikator selanjutnya menimbang berat wadah (A). Menimbang sampel \pm 1 g ke dalam cawan porselin yang telah diketahui bobotnya, berat wadah + sampel (B). Memanaskan sampel ke dalam tanur dengan suhu $600^{\circ} \mathrm{C}$ selama 4 jam. Memindahkan cawan dari tanur kemudian mendinginkannya ke dalam desikator selama 2 jam kemudian ditimbang hingga selisih massa dibawah $0,0005 \mathrm{~g}$, berat wadah + sampel (setelah di oven) (C), menimbang berat wadah setelah dari oven (D)

Kadar Abu (\%) $=\frac{C-D}{B-C} \times 100 \%$

Dimana : $\mathrm{A}=$ berat wadah

$\mathrm{B}=$ berat wadah + sampel

$\mathrm{C}=$ berat wadah + sampel (setelah di oven $)$ 
$\mathrm{D}=$ berat wadah setelah dari oven

b. Kadar air

Memanaskan cawan porselin ke dalam oven pada suhu $105^{\circ} \mathrm{C}$ selama 30 menit, kemudian mendinginkan di dalam desikator selanjutnya menimbang bobot kosongnya (A). Menimbang sampel $\pm 1 \mathrm{~g}$ ke dalam cawan porselin yang telah diketahui bobotnya (B). Memanaskan sampel ke dalam oven pada suhu $105^{\circ} \mathrm{C}$ selama 1 jam. Mengangkat cawan kemudian mendinginkanya kedalam deksikator. Selanjutnya menimbang bobotnya hingga menghasilkan selisih massa dibawah $0,0005 \mathrm{~g}$ (C).

$$
\% \text { Air }=\frac{B-C}{B-A} \times 100 \%
$$

Dimana : $\quad \mathrm{A}=$ bobot kosong

$\mathrm{B}=$ bobot sampel

$\mathrm{C}=$ selisih massa

\section{c. Nilai Kalor}

Pengukuran nilai kalor dilakukan dengan menggunakan alat bom kalorimeter parr 1341. Mula-mula menimbang sampel $\pm 1 \mathrm{~g}$ ke dalam cawan. Menyiapkan rangkaian bom kalorimeter dan cawan ke rangkaian bom kalorimeter menghubungkan rangkaian bom kalorimeter dengan kawat platina dengan berbentuk V. Memasukan aquades sebanyak $1 \mathrm{ml}$ ke dalam bejana bom kalorimeter dan memasang rangkaian penutup pada wadahnya. Mengisi bom kalorimeter dengan oksigen pada tekanan 25-30 atm. Memasukan $\pm 2 \mathrm{~L}$ air pada. jaket bom kalorimeter dan memasang wadah bom kalorimeter pada jaketnya kemudian ditutup. Menjalankan karet dengan menekan tombol ON pada termometer. Mencatat kenaikan suhu pada menit ke 5-10 dan menekan tombol burning pada menit ke-10. Mencatat kenaikan suhunya hingga menit 24 menekan tombol OFF pada termometer dan menghentikan perputaran karet dengan memutar ke kanan. Membuka penutup dan mengambil wadah. Membersihkan dari air dan membuka aliran gasnya. Membilas seluruh permukaan wadah bom kalorimeter dengan aquades dan menitrasi hasil pembakaran dengan $\mathrm{Na}_{2} \mathrm{CO}_{3} \quad 0,07 \mathrm{~N}$ dengan menggunakan indikator MO. Mencatat volume titran. Menghitung panjang kawat yang terbakar. Menghitung nilai Kalor sampel.

$$
\mathrm{Hg}=\frac{t w-e}{m}
$$

Dimana :

$$
\begin{aligned}
& \mathrm{m}=\text { massa sampel } \\
& \mathrm{t}=\text { temperatur }{ }^{\circ} \mathrm{C} \\
& \mathrm{W}=\text { energi yang setara dengan kalorimeter dalam kalori per }{ }^{\circ} \mathrm{C} \\
& \mathrm{E}=\text { panjang kawat yang terbakar }
\end{aligned}
$$

\section{HASIL DAN ANALISIS}

Uji Fisika

Kualitas briket yang dihasilkan dapat diketahui dengan melakukan uji kerapatan yang disajikan pada Tabel 1.

Tabel 1. Nilai kerapatan dari perbandingan bahan briket

\begin{tabular}{ccccc}
\hline \multirow{2}{*}{ Spesimen } & \multicolumn{2}{c}{ Komposisi } & Nilai Kerapatan $\left(\mathrm{g} / \mathrm{cm}^{3}\right)$ \\
\hline & Serbuk Kulit kopi & Serbuk kayu & Perekat \\
\hline I & $80 \%$ & $10 \%$ & $10 \%$ & 0,79 \\
II & $45 \%$ & $45 \%$ & $10 \%$ & 0,75 \\
III & $10 \%$ & $80 \%$ & $10 \%$ & 0,89 \\
\hline
\end{tabular}




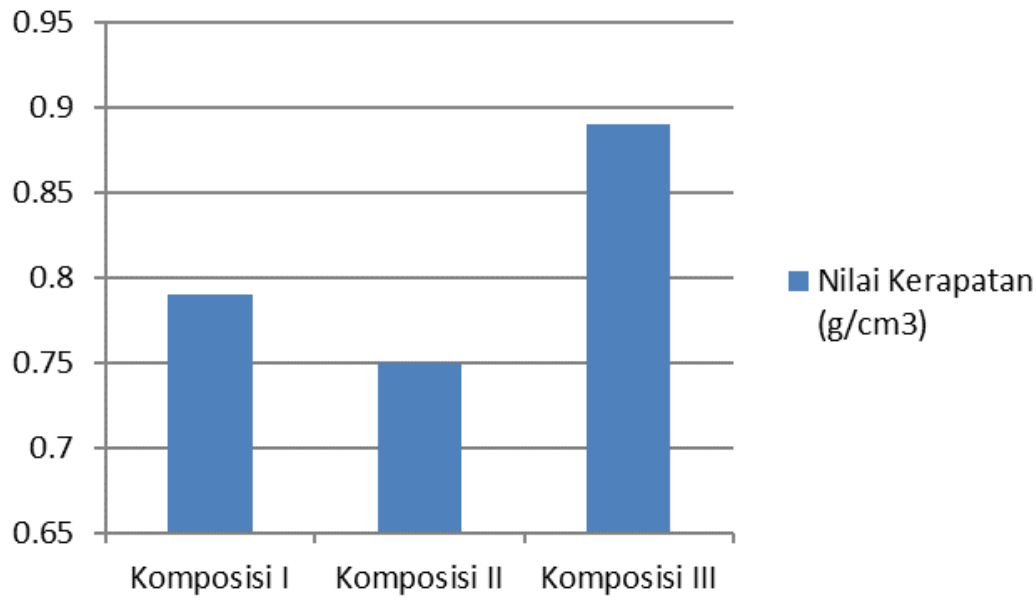

Gambar 2. Grafik Nilai Kerapatan pada setiap komposisi.

Kerapatan atau berat jenis yang tinggi menunjukkan kekompakan arang briket yang dihasilkan. Semakin besar kerapatan bahan bakar maka nilai kalornya semakin tinggi. Pada komposisi III nilai kerapatan paling tinggi karena jumlah serbuk kayu paling banyak. Hal ini disebabkan dengan adanya perlakuan gaya tekan secara manual maka partikel-partikel arang akan mengalami pemampatan. sesuai dengan gaya tekan yang diberikan. Semakin tinggi pengempaan maka akan menyebabkan jarak pori-pori partikel briket akan mengalami penyempitan (semakin rapat) dan briket akan semakin padat, sementara untuk volume briket dalam kondisi yang sama akan diperoleh densitas yang tinggi [13]. Perbedaan jenis bahan baku sangat mempengaruhi nilai kerapatan briket arang yang dihasilkan. Nilai kerapatan dipengaruhi oleh massa jenis bahan penyusun briket [14].

\section{Uji Kimia}

Kualitas briket yang dihasilkan juga dapat diketahui dengan melakukan uji kimia yang terdiri dari uji kadar air, kadar abu, dan nilai kalor yang disajikan pada Tabel 2.

Tabel 2. Hasil Pengujian Dan Perbandingan Komposisi

\begin{tabular}{ccccccc}
\hline Komposisi & $\begin{array}{c}\text { Serbuk } \\
\text { Kulit } \\
\text { kopi }\end{array}$ & $\begin{array}{c}\text { Serbuk } \\
\text { kayu }\end{array}$ & Perekat & $\begin{array}{c}\text { Nilai } \\
\text { Kalor } \\
(\mathrm{kal} / \mathrm{g})\end{array}$ & $\begin{array}{c}\text { Kadar Air } \\
(\%)\end{array}$ & $\begin{array}{c}\text { Kadar } \\
\text { Abu (\%) }\end{array}$ \\
\hline I & $80 \%$ & $10 \%$ & $10 \%$ & 6052 & 7,56 & 11,61 \\
II & $45 \%$ & $45 \%$ & $10 \%$ & 6122 & 5,97 & 11,62 \\
III & $10 \%$ & $80 \%$ & $10 \%$ & 6333 & 4,42 & 7,87 \\
\hline
\end{tabular}

Uji kerapatan briket merupakan sifat fisik briket yang berhubungan dengan kekuatan briket. Semangkin besar kerapatan bahan bakar maka laju pembakaran akan semangkin lama. Hal ini menyebabkan briket yang memiliki berat jenis yang besar memiliki laju pembakaran yang lebih lama dan nilai kalor yang tinggi jika dibandingkan dengan briket yang memiliki kerapatan yang lebih rendah. Sehingga semangkin tinggi keraptan briket semakin tinggi pula nilai kalor yang dihasilkan [15]. Besarnya nilai kalor pada briket dipengaruhi oleh kadar air dan densitas dari bahan yang dibakar. Semakin kecil nilai kadar air, maka semakin tinggi nilai densitas dan nilai kalornya. Pada hasil penelitian komposisi I menghasilkan nilai kalor sebesar $6052 \mathrm{kal} / \mathrm{gr}$, komposisi II menghasilkan nilai kalor sebesar $6122 \mathrm{kal} / \mathrm{gr}$ dan komposisi III menghasilkan nilai kalor sebesar $6333 \mathrm{kal} / \mathrm{gr}$. Dari ketiga sampel tersebut apabila dibandingkan dengan Standar mutu briket Indonesia dengan nilai kalor sebesar $5000 \mathrm{kal} / \mathrm{gr}$, maka ketiga komposisi tersebut sudah memenuhi standar dari kualitas briket. Besarnya kerapatan juga disebabkan ikatan antara serbuk kayu dan kulit kopi mempunyai 
ikatan antara serat yang kompak dan kuat karena serbuk yang kecil mempunyai luasan permukaan yang besar sehingga dapat menyebabkan nilai kerapatan briket tinggi.

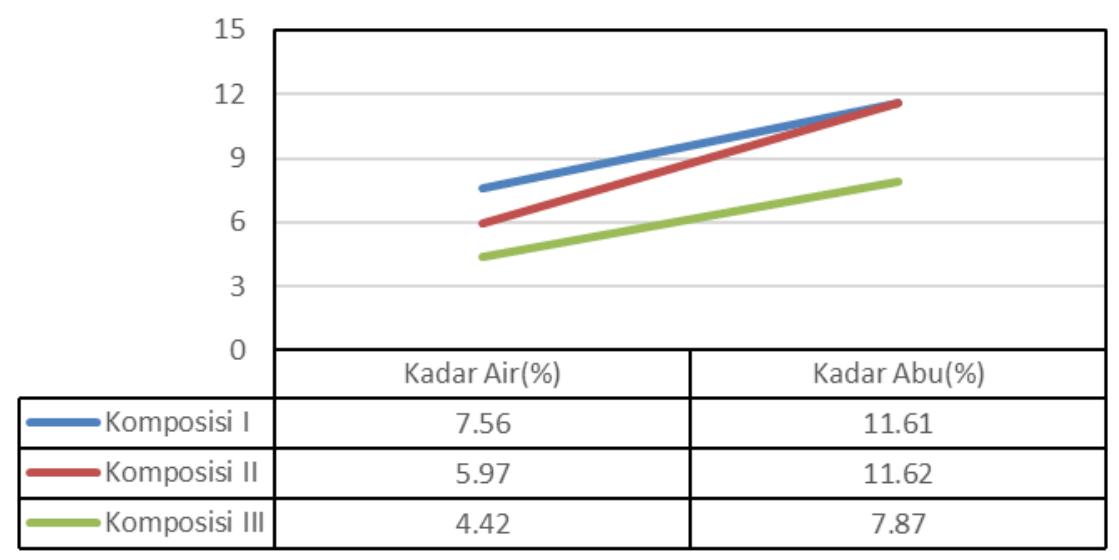

Gambar 3. Grafik Kadar Air dan Kadar Abu

Pada Gambar 3, nilai kadar air dipengaruhi kurang padatnya briket pada proses pencetakan sehingga kadar air yang teruapkan tidak konstan dan masih adanya pengaruh udara diluar lingkungan pada proses pendinginan yang dilakukan secara manual (di ruangan terbuka). Serbuk kulit kopi sulit menyerap air karena mempunyai pori-pori yang kecil sehingga pada briket yang mempunyai komposisi III menghasilkan kadar air yang sedikit. Kadar air briket arang yang dihasilkan pada komposisi I (7,57\%), komposisi II (5,97\%), komposisi III $(4,42 \%)$ hasil ini apabila dibandingkan dengan kadar air hasil analisis kualitas briket arang Jepang, Inggris, Amerika, dan Indonesia maka hasil penelitian sebagan telah memenuhi standar kualitas. Dimana standar kualitas jepang $(6-8 \%)$. ASTM $(\leq 6,2 \%)$ dan SNI $(\leq 8 \%) \quad[16]$.

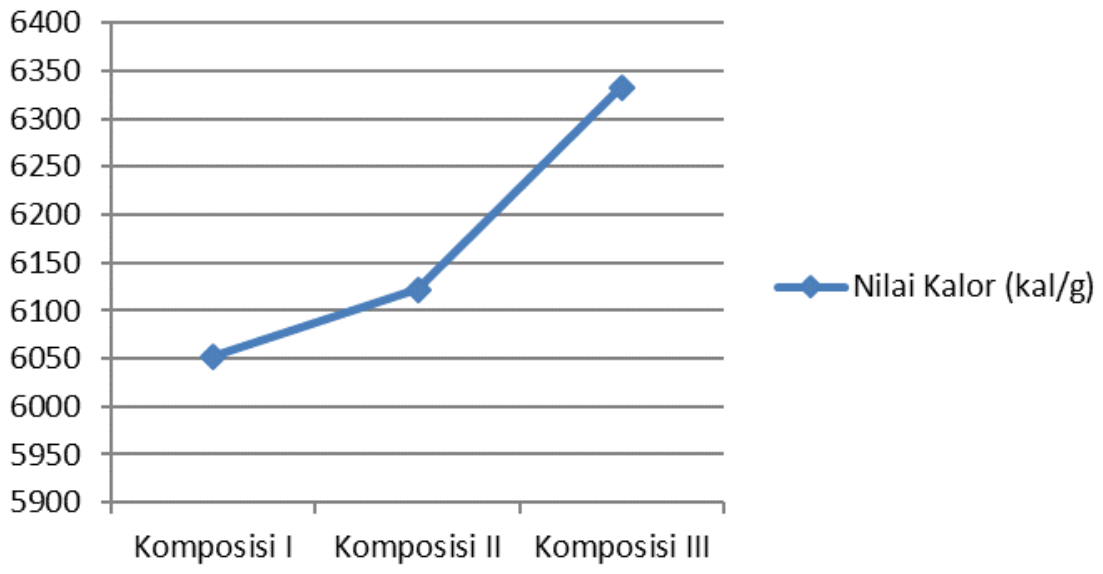

Gambar 4. Grafik Nilai Kalor

Kadar abu merupakan bagian yang tersisa dari hasil pembakaran, abu yang dimaksud adalah abu sisa pembakaran briket [17]. Sisa dari pembakaran yang sudah tidak memiliki unsur karbon dan nilai kalor lagi. Nilai kadar abu menunjukkan jumlah sisa dari akhir proses pembakaran berupa zat - zat mineral yang tidak hilang selama proses pembakaran atau pirolisis. Hasil uji kadar abu SNI 01-6235-2000 tentang briket arang, kadar abu yang diperbolehkan tidak melebihi nilai 8\%. Pada penelitian ini, kadar abu yang dihasilkan pada komposisi III sesuai standar yang ditentukan Indonesia (SNI). kadar abu briket arang standar kualitas jepang (3-6\%), Amerika 8,3\%, Inggris (8,3\%) dan SNI-01-6235-2000 ( $8 \%$ \%) [16].

\section{KESIMPULAN}

Dari analisa yang telah dilakukan dengan pengujian maka dapat disimpulkan bahwa ada pengaruh komposisi briket dengan campuran kulit kopi dan serbuk kayu terhadap nilai kalor, kadar air, kadar abu, dan uji kerapatan. Pada komposisi III nilai kerapatan paling tinggi karena jumlah serbuk kayu paling banyak. Hal ini disebabkan dengan adanya perlakuan gaya tekan secara manual maka partikel-partikel arang akan mengalami 
Pengolahan Bioarang sebagai Pengganti Biogas untuk Mendukung Proses Roasting Pengolahan Kopi.. pemampatan sesuai dengan gaya tekan yang diberikan Pada hasil penelitian komposisi I menghasilkan nilai kalor sebesar $6052 \mathrm{kal} / \mathrm{gr}$, komposisi II menghasilkan nilai kalor sebesar $6122 \mathrm{kal} / \mathrm{gr}$ dan komposisi III menghasilkan nilai kalor sebesar 6333 kal/gr. Hasil uji kadar abu SNI 01-6235-2000 tentang briket arang, kadar abu yang diperbolehkan tidak melebihi nilai $8 \%$. Pada penelitian ini, kadar abu yang dihasilkan pada komposisi III sesuai standar yang ditentukan.

\section{DAFTAR PUSTAKA}

[1] Nuriana, W., Suryanto, A., \& Kamal, M., "Calorific value analysis, reduction of period weight, reaction rate, activation energy of old coconut, young coconut waste briquette burning, cocoa." In IOP Conference Series: Materials Science and Engineering, Vol. 588, No. 1, p. 012004. IOP Publishing. 2019, August.

[2] Dewi, R., \& Hasfita, F., "Pemanfaatan Limbah Kulit Jengkol (Pithecellobium Jiringa) Menjadi Bioarang Dengan Menggunakan Perekat Campuran Getah Sukun Dan Tepung Tapioka," Jurnal Teknologi Kimia Unimal, 5(1), pp. 105-123, 2017.

[3] Anonim, "Sustainable Energy dan Upaya Ketahanan Energi Nasional," diakses dari: https://kemlu.go.id/portal/id/read/171/halaman_list_lainnya/sustainable-energy-dan-upaya-ketahananenergi-nasional, pada tanggal 11 november 2019 jam 07.00 wib, 2019.

[4] Caraka, R. E., "Simulasi Kalkulator Energi Baru Terbarukan (EBT) Guna Memenuhi Ketahanan Energi di Indonesia", Statistika: Journal of Theoretical Statistics and Its Applications, 16(2), pp.77-88, 2016.

[5] Kurniawati, L., "Kebijakan Dana Ketahanan Energi Sebagai Upaya Mewujudkan Ketahanan Energi Sebagai Upaya Mewujudkan Ketahanan Energi Nasional: Konsep dan Tantangannya", Jurnal Manajemen Keuangan Publik, 1(1), pp. 29-41, 2017.

[6] Subarjo, A. H., Mardwianta, B., \& Wicaksono, A. B., "Efisiensi kompor surya parabola berreflektor cermin untuk menunjang ketahanan energi", Jurnal surya energy, 4(1), pp. 345-352, 2020.

[7] Budiawan, Lucky dkk, "Pembuatan Dan Karakterisasi Briket Bioarang Dengan Variasi Komposisi Kulit Kopi”, Jurnal Bioproses Komoditas Tropis Vol. 2 No. 2 November 2015, hal 152-160, 2015,.

[8] Gunawan, Budi, "Pembuatan Biobriket Dari Limbah Bottom Ash PLTU Dengan Biomassa Cangkang Kopi”. Jurnal SIMETRIS, Vol. 6 No. 2, November 2015.

[9] Fitri, Nursyah, "Pembuatan Briket Dari Campuran Kulit Kopi (Coffea Arabica) Dan Serbuk Gergaji Dengan Menggunakan Getah Pinus (Pinus Merkusii) Sebagai Perekat", Skripsi Jurusan Kimia Fakultas Sains dan Teknologi, 2015.

[10] Hilwatullisan, "Pemanffatan Limbah Kulit Kopi Dan Serbuk Gergaji Menjadi Briket Sebagai Sumber Energi Alternatif'. Jurnal KINETIKA, Vol. 6 No. 2, 2015.

[11] Masthura, M., "Analisis Fisis dan Laju Pembakaran Briket Bioarang Dari Bahan Pelepah Pisang", Elkawnie: Journal of Islamic Science and Technology, 5(1), pp. 58-66, 2019.

[12] Setiawan, A., Andrio, O., \& Coniwanti, P., "Pengaruh komposisi pembuatan biobriket dari campuran kulit kacang dan serbuk gergaji terhadap nilai pembakaran", Jurnal Teknik Kimia, 18(2), 2012.

[13] Nasruddin \& Affandy, Risman., "Karakteristik Briket dari Tongkol jagung Dengan Perekat Tetes Tebu dan Kanji”, Jurnal Dinamika Penelitian Industri., Vol. 22, No. 2 Tahun 2011. Hal : 1 - 10, 2011.

[14] Marchel, W. I., Freeke, P., \& Dedie, T., "Analisis Perbedaan Jenis Bahan Dan Massa Pencetakan Briket Terhadap Karakteristik Pembakaran Briket Pada Kompor Biomassa”, In COCOS , Vol. 1, No. 5, 2019, September.

[15] Sinurat, Erikson, "Studi Pemanfaatan Briket Kulit Jambu Mete Dan Tongkol Jagung Sebagai Bahan Bakar Alternatif", Tugas Akhir Jurusan Mesin Fakultas Teknik Universitas Hasanuddin, 2011.

[16] Radam, R. M., Lusyiani, L., Ulfah, D., Sari, N. M., \& Violet, V., "Kualitas Briket Arang Dari Kulit Sabut Buah Nipah (Nypa fruticans WURMB) Dalam Menghasilkan Energi. The qualty of charcoal briquettes that made from nypah (nypa fruticans wurmb) outshel to product energy", Jurnal Hutan Tropis, 6(1), pp. 52-62, 2018.

[17] Putri, R. E., \& Andasuryani, A., "Studi mutu briket arang dengan bahan baku limbah biomassa", Jurnal Teknologi Pertanian Andalas, 21(2), pp. 143-151, 2017. 
